\title{
Stereochemistry of phase-1 metabolites of mephedrone determines their effectiveness as releasers at the serotonin transporter
}

Felix P. Mayer ${ }^{\mathrm{a}, 1}$, Daniela Cintulova ${ }^{\mathrm{b}}$, Dorothea A. Pittrich ${ }^{\mathrm{a}}$, Laurin Wimmer ${ }^{\mathrm{b}}$, Dino Luethi ${ }^{\mathrm{c}}$, Marion Holy ${ }^{\mathrm{a}}$, Kathrin Jaentsch ${ }^{\mathrm{a}}$, Sonja Tischberger ${ }^{\mathrm{d}}$, Guenter Gmeiner ${ }^{\mathrm{d}}$, Marius C. Hoener ${ }^{\mathrm{e}}$, Matthias E. Liechtic ${ }^{\mathrm{c}}$ Marko D. Mihovilovic ${ }^{\mathrm{b}}$, Harald H. Sitte ${ }^{\mathrm{a}, \mathrm{f}}$

${ }^{a}$ Medical University of Vienna, Center for Physiology and Pharmacology, Institute of Pharmacology, Vienna, Austria

${ }^{b}$ Institute of Applied Synthetic Chemistry, Vienna University of Technology, Vienna, Austria

${ }^{c}$ University Hospital Basel and University of Basel, Division of Clinical Pharmacology and Toxicology,

Department of Biomedicine, Basel, Switzerland

${ }^{d}$ Doping Control Laboratory, Seibersdorf Labor GmbH, Seibersdorf, Austria

${ }^{e}$ Neuroscience Research, pRED, Roche Innovation Center Basel, F. Hoffmann-La

Roche Ltd, Basel, Switzerland

${ }^{\mathrm{f}}$ Center for Addiction Research and Science - AddRess, Medical University Vienna, Waehringerstrasse 13A, 1090 Vienna, Austria

${ }^{1}$ Present Address: Department of Biomedical Science, Charles E. Schmidt College of Medicine, FL, USA

\section{Correspondence}

Harald H Sitte, harald.sitte@meduniwien.ac.at

Medical University of Vienna, Center for Physiology and Pharmacology, Institute of Pharmacology, Waehringerstrasse 13a, A-1090 Vienna, Austria 


\section{Abstract}

Mephedrone (4-methyl- $N$-methylcathinone) is a psychostimulant that promotes release of monoamines via the high affinity transporters for dopamine (DAT), norepinephrine (NET) and serotonin (SERT). Metabolic breakdown of mephedrone results in bioactive metabolites that act as substrate-type releasers at monoamine transporters and stereospecific metabolism of mephedrone has been reported. This study compared the effects of the enantiomers of the phase-1 metabolites nor-mephedrone, 4-hydroxytolylmephedrone (4-OH-mephedrone) and dihydro-mephedrone on (i) DAT, NET and SERT mediated substrate fluxes, (ii) determined their binding affinities towards a battery of monoamine receptors and (iii) examined the relative abundance of the enantiomers in human urine.

Each of the enantiomers tested inhibited uptake mediated by DAT, NET and SERT. No marked differences were detected at DAT and NET. However, at SERT, the $S$ enantiomers of nor-mephedrone and 4-OH-mephedrone were several times more potent than the corresponding $R$-enantiomers. Moreover, the $R$-enantiomers were ineffective as releasers at SERT. $S$-nor-mephedrone displayed moderate affinities towards human alpha1 , human $5-\mathrm{HT}_{2 \mathrm{~A}}$ and rat and mouse trace amine-associated receptor 1 .

These results demonstrate that stereochemistry dictates the pharmacodynamics of the phase- 1 metabolites of mephedrone at SERT, but not at DAT and NET, which manifests in marked differences in their relative potencies, i.e. DAT/SERT ratios. Chiral analysis of urine samples demonstrated that nor-mephedrone predominantly exists as the $S$ enantiomer. Given the asymmetric abundance of the enantiomers in biological samples, these findings may add to our understanding of the subjective effects of administered mephedrone, which indicate pronounced effects on the serotonergic system. 
Keywords: New psychoactive substance, dopamine, serotonin, cathinones, mephedrone, stereoisomers

\section{Abbreviations}

5-HT, serotonin; CYP, Cytochrome P450 enzyme; DAT, dopamine transporter; MAT, monoamine transporter; MDMA, 3,4-methylenedioxymethamphetamine; MPP+ , 1methyl-4-phenylpyridinium; NET norepinephrine transporter; NPS, new psychoactive substance; SERT, serotonin transporter. 


\section{Introduction}

Mephedrone is a methcathinone analogue with stimulant properties. Although mephedrone was synthesized in 1929, first reports on its abuse appeared in 2007 (Kelly, 2011; Pedersen et al., 2013). Together with its congeners 3,4methylenedioxypyrovalerone (MDPV) and 3,4-methylenedioxymethcathinone (methylone), mephedrone belongs to a series of cathinones that received major attention from the media as so-called "bath salts" (Spiller et al., 2011), thus creating public awareness of new psychoactive substances (NPS) that are introduced into global drug markets (Brandt et al., 2014). NPS provide synthetic and easily accessible alternatives to well-established and scheduled drugs (Baumann and Volkow, 2016). Psychostimulant-type NPS generally fall into the classes of phenethylamines or cathinones (Tyrkko et al., 2016). Some NPS became established within drug markets and abuse continues despite their ban whereas others appear only locally and/or temporarily (World Drug Report 2016). Mephedrone was banned in most western countries in 2010 to 2011 (Green et al., 2014). However, converging lines of evidence indicate persistent abuse of this compound (Archer et al., 2013; Archer et al., 2014; Castiglioni et al., 2015; Salomone et al., 2016; Styszko et al., 2016), indicating that mephedrone became a widely accepted drug for recreational consumption in some regions (Hockenhull et al., 2016; Ordak et al., 2018).

Pharmacologically, mephedrone exerts its effects by targeting the high-affinity monoamine transporters (MATs) for dopamine (DAT), norepinephrine (NET) and serotonin (5-HT, SERT), members of the solute carrier 6 family (Baumann et al., 2012; Eshleman et al., 2013; Hadlock et al., 2011; Martinez-Clemente et al., 2012; Simmler et al., 2013). DAT, NET and SERT retrieve monoamines from the extracellular space and terminate their activity at the pre- and postsynaptic receptors (Kristensen et al., 2011). Monoaminergic signalling is involved in various aspects of brain function, including motor function, motivation and reward. Thus, MATs are associated with a rich pharmacology and serve as molecular targets for clinically relevant (e.g. antidepressants) and recreationally ingested compounds (Sitte and Freissmuth, 2015; Torres et al., 2003). Generally, drugs that interfere with MAT-function are of two types: a) non-transported inhibitors, e.g. cocaine or antidepressants, which trap the transporter in a specific conformational state and arrest the transport cycle and $b$ ) substrate-type releasers. The latter are actively transported by MATs and promote reverse transport of cytosolic monoamines across the plasma membrane (Sitte and 
Freissmuth, 2015). Mephedrone acts as a non-selective substrate-type releaser at DAT, NET and SERT (Baumann et al., 2012; Eshleman et al., 2013; Mayer et al., 2016; Pifl et al., 2015; Simmler et al., 2013) and thus induces transporter-mediated release of monoamines.

A variety of cathinones and phenethylamines contain a chiral carbon atom and exist as stereoisomers. Stereochemistry has a bearing on the neurochemistry and behavior associated with psychostimulants. For instance, racemic methcathinone was associated with neurotoxicity in dopaminergic neurons, whereas only $S$-methcathinone caused toxic effects on serotonergic neurons (Sparago et al., 1996). $S$-MDMA was found to be more potent than R-MDMA in inducing substrate-efflux at SERT (Rudnick and Wall, 1992) and both enantiomers differed in their endocrine and neurochemical effects (Murnane et al., 2010). Stereospecific effects have also been reported for mephedrone, both in vitro and in vivo. The $R$ - and $S$-enantiomers of mephedrone are equipotent as releasers at DAT and NET. At SERT, however, $S$-mephedrone is 40 times more potent than $R$-mephedrone (Gregg et al., 2015). In the same study, only $R$-mephedrone resulted in conditioned place preference and $R$-mephedrone produced greater intracranial selfstimulation and sensitization to repetitive movements. In rats trained to self-administer the stereoisomers of mephedrone, $R$-mephedrone was associated with higher break points than $S$-mephedrone under progressive ratio access conditions (Philogene-Khalid et al., 2017b).

In contrast to the prototypical stimulant amphetamine ("speed"), mephedrone exerts additional entactogenic effects and drug users report that the subjective effects resemble those of 3,4-methylendioxymethylamphetamine (MDMA, "ecstasy") (Schifano et al., 2011). Simmler et al. (Simmler et al., 2013) concluded that the entactogenic effects of mephedrone arise from its ability to release serotonin in the brain in vivo to a greater extent when compared to dopamine (Baumann et al., 2012), resembling the effects of MDMA but contrasting those of amphetamine (Baumann et al., 2012; Kehr et al., 2011). Racemic mephedrone, however, does not favor SERT over DAT (Baumann, 2012, Eshleman, 2013, Hadlock, 2011). Enzymatic degradation of mephedrone gives rise to various phase-1 metabolites (Pedersen et al., 2013) (Figure 1). Our laboratory demonstrated that the phase- 1 metabolites of mephedrone possess bioactive properties, thus might contribute to the actions of the parental compound. Systemic administration of the $\mathrm{N}$-demethylated metabolite nor-mephedrone results in a profound increase in extracellular serotonin but has only blunted effects on extracellular dopamine in nucleus 
accumbens (Mayer et al., 2016). Recently, stereospecific metabolism of mephedrone was reported (Castrignano et al., 2017). We therefore hypothesized that stereospecific pharmacokinetics and pharmacodynamics of the phase-1 metabolites may contribute to the overall effects of mephedrone. We performed in vitro assays to determine the effects of nor-mephedrone, 4-hydroxytolyl-mephedrone (4-OH-mephedrone) and dihydromephedrone in their enantiopure form on monoamine transporters and receptors. We have also analyzed human urine samples for the abundance of the stereoisomers of normephedrone and 4-OH-mephedrone. 
2. Methods (1948 words)

\subsection{Cell Culture}

Human embryonic 293 cells (HEK293 cells) were maintained at a subconfluent state in humidified atmosphere $\left(37^{\circ} \mathrm{C}, 5 \% \mathrm{CO}_{2}\right)$ in Dulbecco's Modified Eagle Medium (DMEM), containing $10 \%$ heat-inactivated fetal calf serum (FCS), streptomycin (100 $\mu \mathrm{g} \mathrm{x} 100 \mathrm{~mL}$ 1) and penicillin (100 $\left.\mathrm{U} \times 100 \mathrm{~mL}^{-1}\right)$. Geneticin $\left(50 \mu \mathrm{g} \times \mathrm{mL}^{-1}\right)$ was added to select HEK293 cells stably expressing the human isoforms of DAT, NET and SERT as described in (Mayer et al., 2017). For uptake inhibition experiments cells expressing the desired transporter were seeded $(40,000$ cells per well in a final volume of $200 \mu \mathrm{L})$ onto poly-Dlysine (PDL) coated 96-well plates 24 hours prior to the experiment. The same procedure was applied for release experiments, with the only modification that PDLcoated glass-coverslips (diameter $5 \mathrm{~mm}$ ) were placed into the 96-well plates (Mayer et al., 2017).

Cells used for membrane preparations for the radioligand binding assays were cultured and prepared as described previously (Luethi et al., 2018b). The cells were harvested by adding trypsin/ethylenediaminetetraacetic acid (EDTA), washed with ice-cold PBS, pelleted by centrifugation (1000 rpm for 5 minutes at $4^{\circ} \mathrm{C}$ ), and frozen and stored at $80^{\circ} \mathrm{C}$. The frozen pellets were then suspended in $20 \mathrm{~mL}$ (receptor binding) or $400 \mathrm{~mL}$ (transporter binding) HEPES-NaOH (20 mM, pH 7.4) containing 10 mM EDTA, and homogenized at 14,000 rpm for 20 seconds (receptor binding) or 10,000 rpm for 15 seconds (transporter binding). The homogenates were then centrifuged at 48,000 $\mathrm{g}$ and $4^{\circ} \mathrm{C}$ for 30 minutes and the supernatants were discarded. The pellets were then resuspended in $20 \mathrm{ml}$ HEPES-NaOH (20 mM, pH 7.4) containing 0.1 mM EDTA and homogenized at 14,000 rpm for 20 seconds. Centrifugation and removal of the supernatant was repeated, before the final pellet was resuspended in $\mathrm{HEPES}-\mathrm{NaOH}$ containing 0.1 mM EDTA and homogenized. The following transfected cell lines were used for the binding assays: HEK293 cells (5-HT1A, 5-HT2A, 5-HT2C, TAAR1, hDAT, hNET, and hSERT), Chinese hamster ovary (CHO) cells $\left(\alpha_{1 \mathrm{~A}}\right)$ and Chinese hamster lung (CHL) cells $\left(\alpha_{2 A}\right)$. 


\subsection{Uptake Inhibition Experiments}

For uptake inhibition assays, cell culture medium was replaced with Krebs-HEPES buffer (KHB: $25 \mathrm{mM}$ HEPES, $120 \mathrm{mM} \mathrm{NaCl}, 5 \mathrm{mM} \mathrm{KCl}, 1.2 \mathrm{mM} \mathrm{CaCl}_{2}$, and $1.2 \mathrm{mM} \mathrm{MgSO}_{4}$ and 5 mM D-glucose, pH adjusted to 7.3) (200 $\mu \mathrm{L}$ per well). Subsequently, the cells were incubated with increasing concentrations of the substance of interest. After 300 seconds, tritiated substrates (20 nM [ $\left.{ }^{3} \mathrm{H}\right] \mathrm{MPP}^{+}$for DAT and NET and $100 \mathrm{nM}\left[{ }^{3} \mathrm{H}\right] 5-\mathrm{HT}$ for SERT) were added. After 180 (DAT and NET) or 60 seconds (SERT), the tritiated substrates were removed and the cells were washed with ice-cold KHB $(200 \mu \mathrm{L}$ per well). Finally, the cells were lysed with $1 \%$ sodium dodecyl sulphate (SDS, $100 \mu \mathrm{L}$ per well) and the amount of tritium within the cells was determined by use of a beta-scintillation counter. Nonspecific uptake was determined in the presence of $10 \mu \mathrm{M}$ mazindol (DAT, NET) or $10 \mu \mathrm{M}$ paroxetine (SERT) and subtracted. Uptake in the absence of the substance of interest was defined as $100 \%$ uptake. The IC50 values were determined by non-linear regression fits (GraphPad Prism version 5.0; $\log$ (inhibitor) vs. response -variable slope four parameters $\left(\mathrm{Y}=\right.$ Bottom $+($ Top-Bottom $) /\left(1+10^{\wedge}((\right.$ LogIC50-X)*HillSlope $))$; fitting method: Least squares (ordinary) fit without weighting to minimize the absolute distances squared) as described in (Mayer et al., 2017).

\subsection{Release Experiments}

Dynamic superfusion experiments were performed as previously described (Mayer et al., 2017; Sitte et al., 2000). Briefly, SERT expressing HEK293 cells were grown on PDLcoated glass coverslips and pre-loaded with $\left[{ }^{3} \mathrm{H}\right] 5$-HT by exposing the cells to $0.4 \mu \mathrm{M}$ $\left[{ }^{3} \mathrm{H}\right] 5-\mathrm{HT}$ (in KHB) for 20 minutes at $37^{\circ} \mathrm{C}$. Subsequently, the cells were placed in superfusion chambers with a volume of $200 \mu \mathrm{L}$ and superfused with KHB at a flow rate of $0.7 \mathrm{~mL}$ per minute for 40 minutes to establish a stable baseline before the collection of 2 minute-fractions was started. After three basal fractions, the cells were superfused with $\mathrm{KHB}$ containing the substance of interest $(0,1,3,10,30$ and $100 \mu \mathrm{M})$ for five fractions. Finally, the cells were superfused with 1\% SDS for three fractions to determine the total amount of radioactivity within the cells at the end of the experiment. The amount of tritium within the superfusates was determined with a beta-scintillation counter and the release of $\left[{ }^{3} \mathrm{H}\right] 5-\mathrm{HT}$ was expressed as a fractional rate, i.e. the radioactivity present within each fraction was expressed as the percentage of the total radioactivity present at the beginning of that fraction (Sitte et al., 2000). 
The superfusion apparatus has 12 individual chambers. Hence, each independent observation allowed for the monitoring of six different concentrations (each in duplicate). To monitor inter-experimental consistency, randomly selected concentrations were included in following experiments, giving rise to individual differences in sample sizes in Figure 3 and 4.

\subsection{Receptor and Transporter Binding and Activation Assays}

Radioligand binding assays were performed as described in detail for each receptor and transporter in (Luethi et al., 2018b). The membrane preparations that overexpressed the respective receptors or transporters (human genes, with the exception of rat and mouse genes for TAAR1) were incubated with radiolabelled ligands and ligand displacement by the compounds was measured. The difference between total binding (binding buffer alone) and nonspecific binding (in the presence of specific competitors) was determined to be specific binding. The radioligands and competitors are listed in Table 1.

$\mathrm{IC}_{50}$ values were derived from three concentration-effect curves using 10 different concentrations. The validity of this measurement is dependent on the amount of single data points (concentration-effect measurements) and the appropriate selection of sufficient points within the slope of the curve ( $>5$ for each experiment). Thus, the amount and level of concentrations tested defines accurate $\mathrm{IC}_{50}$ values rather than the number of experiments (with potentially fewer concentrations or concentrations not within the slope). GraphPad was used to derive each $\mathrm{IC}_{50}$ value from the modeled curves using in total 30 data points by logistic regression. The Cheng-Prusoff equation was used to calculate $K_{\mathrm{i}}$ values. No observed affinity within a concentration range indicates that there was no binding at the highest tested concentration as well as no binding at 9 different lower concentrations.

\begin{tabular}{|c|c|c|c|c|c|c|}
\hline $\begin{array}{l}\text { Receptor/ } \\
\text { Transporter }\end{array}$ & hTAAR1 & rTAAR1 & mTAAR1 & h5-HT $1 \mathrm{~A}$ & h5-HT $2 \mathrm{~A}$ & $\mathrm{~h} 5-\mathrm{HT}_{2 \mathrm{C}}$ \\
\hline Radioligand & $\begin{array}{l}{\left[{ }^{3} \mathrm{H}\right] \mathrm{RO5166}} \\
017\end{array}$ & $\begin{array}{l}{\left[{ }^{3} \mathrm{H}\right] \mathrm{RO} 516601} \\
7\end{array}$ & $\begin{array}{l}{\left[{ }^{3} \mathrm{H}\right]-8-\mathrm{OH}-} \\
\text { DPAT }\end{array}$ & $\begin{array}{l}{\left[{ }^{3} \mathrm{H}\right] \text { Ketanseri }} \\
\mathrm{n}\end{array}$ & FLIPR assay & $\begin{array}{l}{\left[{ }^{3} \mathrm{H}\right]} \\
\text { Mesulergine }\end{array}$ \\
\hline $\begin{array}{l}\text { Non- } \\
\text { specific } \\
\text { binding }\end{array}$ & $\begin{array}{l}10 \mu \mathrm{M} \\
\mathrm{RO} 166017\end{array}$ & $\begin{array}{l}10 \mu \mathrm{M} \\
\mathrm{RO5166017}\end{array}$ & $\begin{array}{l}10 \mu \mathrm{M} \\
\text { pindolol }\end{array}$ & $\begin{array}{l}10 \mu \mathrm{M} \\
\text { spiperone }\end{array}$ & FLIPR assay & $\begin{array}{l}10 \mu \mathrm{M} \\
\text { mianserin }\end{array}$ \\
\hline $\begin{array}{l}\text { Receptor/ } \\
\text { Transporter }\end{array}$ & $\mathrm{h} \alpha_{1 \mathrm{~A}}$ & $\mathrm{~h} \alpha_{2 \mathrm{~A}}$ & hDAT & hNET & hSERT & \\
\hline
\end{tabular}




\begin{tabular}{|l|l|l|l|l|l|l|}
\hline Radioligand & {$\left[{ }^{3} \mathrm{H}\right]$ Prazosin } & $\begin{array}{l}{\left[{ }^{3} \mathrm{H}\right] \text { Rauwolsci }} \\
\text { ne }\end{array}$ & $\begin{array}{l}{\left[{ }^{3} \mathrm{H}\right] \mathrm{WIN} 35,42} \\
8\end{array}$ & $\begin{array}{l}\text { N-methyl- } \\
{\left[{ }^{3} \mathrm{H}\right] \text { Nisoxeti }} \\
\text { ne }\end{array}$ & $\begin{array}{l}{\left[{ }^{3} \mathrm{H}\right] \text { Citalopr }} \\
\text { am }\end{array}$ & \\
\hline $\begin{array}{l}\text { Non- } \\
\text { specific } \\
\text { binding }\end{array}$ & $\begin{array}{l}10 \mu \mathrm{M} \\
\text { chlor- } \\
\text { promazine }\end{array}$ & $\begin{array}{l}10 \mu \mathrm{M} \text { phentol- } \\
\text { amine }\end{array}$ & $\begin{array}{l}10 \mu \mathrm{M} \\
\text { indatraline }\end{array}$ & $\begin{array}{l}10 \mu \mathrm{M} \\
\text { indatraline }\end{array}$ & $\begin{array}{l}10 \mu \mathrm{M} \\
\text { indatraline }\end{array}$ & \\
\hline
\end{tabular}

Table 1: Radioligands and non-specific binding determinants used in receptor and transporter binding assays.

The activation potential at the serotonin $5-\mathrm{HT}_{2 \mathrm{~B}}$ receptor was assessed as described in (Luethi et al., 2018b). HEK293 cells expressing the human 5- $\mathrm{HT}_{2 \mathrm{~B}}$ receptor were incubated in PDLcoated 96-well plates overnight. Thereafter, the growth medium was removed by snap inversion, $100 \mu \mathrm{l}$ of calcium indicator Fluo-4 solution (Molecular Probes, Eugene, OR, USA) was added to each well and the plates were incubated for 45 minutes at $31^{\circ} \mathrm{C}$. The Fluo- 4 solution was then removed by snap inversion before $100 \mu \mathrm{L}$ of Fluo- 4 solution was added again for 45 minutes at $31^{\circ} \mathrm{C}$. After washing the cells, $100 \mu \mathrm{L}$ assay buffer was added. Finally, the plates were placed in a fluorescence imaging plate reader (FLIPR), $25 \mu \mathrm{L}$ of the test drugs diluted in assay buffer was added online and the increase in fluorescence was measured. $\mathrm{EC}_{50}$ values were derived from concentration-response curves using nonlinear regression.

The activation potential at the human TAAR1 was assessed as described in (Luethi et al., 2018b). Recombinant HEK 293 cells expressing the human TAAR1 were harvested and pelleted by centrifugation at $900 \mathrm{rpm}$ for 3 minutes at room temperature. The supernatant was removed and the cell pellet was resuspended in fresh culture medium. The cells were then plated into 96-well plates (100 $\mu \mathrm{l}$ per well, 80,000 cells per well) and incubated for 20 hours at $37^{\circ} \mathrm{C}$. For the cAMP assay, the cell culture medium was removed, and $50 \mu \mathrm{l}$ of PBS (without $\mathrm{Ca}^{2+}$ and $\mathrm{Mg}^{2+}$ ) was added. Thereafter, PBS was removed by snap inversion and 90 $\mu \mathrm{l}$ of Krebs-Ringer bicarbonate buffer containing $1 \mathrm{mM}$ IBMX was added. The plates were then incubated for 60 minutes at $37^{\circ} \mathrm{C}$. All compounds were tested at a broad range of concentrations $(300 \mathrm{pM}-30 \mu \mathrm{M})$ in duplicate and a standard curve $(0.13 \mathrm{nM}-10 \mu \mathrm{M}$ cAMP) was included on each plate. Additionally, a reference plate containing RO5256390, $\beta$ phenylethylamine and p-tyramine was included in each experiment. Typically, $30 \mu \mathrm{l}$ of a compound solution, $30 \mu \mathrm{l}$ of $\beta$-phenylethylamine (as maximal response) or a basal control was added, and the cells were incubated for 40 minutes at $37^{\circ} \mathrm{C}$. Finally, the cells were lysed with $50 \mu$ of detection mix solution containing Ru-cAMP Alexa700 anti-cAMP antibody and 
lysis buffer for 120 minutes at room temperature under heavy shaking. Fluorescence was measured using a NanoScan (IOM reader; $456 \mathrm{~nm}$ excitation wavelength; 630 and $700 \mathrm{~nm}$ emission wavelengths). The FRET signal was calculated as the following: FRET (700 nM) $\mathrm{P} \times$ FRET $(630 \mathrm{nM})$, where $\mathrm{P}=\mathrm{Ru}(700 \mathrm{nM}) / \mathrm{Ru}(630 \mathrm{nM})$.

Receptor and transporter affinity data of a variety of previously published psychedelics and stimulants (Luethi et al., 2018a; Luethi et al., 2018b) verified that the material used was fully binding competent.

\subsection{Enantiomeric profiling of nor-and 4-OH-mephedrone in human urine samples}

After written consent, the urine sample was provided by the Vienna Police Department. The anonymized sample used in the present study tested positive for mephedrone and was obtained during roadside testing of drivers under the influence of drugs in the Vienna area. Prior to analysis of a human urine sample, an HPLC gradient was optimized for the chiral separation of nor-mephedrone and 4-OH-mephedrone. Since direct chiral chromatographic separation of enantiomeric pairs with mass spectrometry (MS) under compatible conditions was not successful, we employed a chiral derivatization protocol described previously (Mohr et al., 2012) to obtain the corresponding diastereoisomers in order to facilitate chromatographic separation. The single enantiomers of normephedrone and 4-OH-mephedrone were treated with $S-(-)-\mathrm{N}-$ (trifluoroacetyl)pyrrolidine-2-carbonyl chloride (L-TPC) under basic conditions, thus yielding their corresponding diastereoisomeric amides. Under these conditions it is possible that partial racemization of the substrates may occur. We found that the racemization in the case of nor-mephedrone was negligible (approximately 1\%), whereas in the case of 4-OH-mephedrone the $S$ - enantiomer tended to slightly $(12 \%)$ racemize towards the $R$-enantiomer (still enabling unequivocal assignment of stereochemistry when utilizing optically pure material). It is noteworthy, that partial racemization was also observed for free-base representatives of this compound series under physiological conditions. Hence, pure isomers were generally employed as hydrochloride salts displaying significantly higher stability of optical purity.

First, the MS behaviour of derivatized metabolites as reference standards was studied in order to find characteristic ionization and fragmentation patterns. Detection and identification of derivatized metabolites were accomplished by analysis by LC-MS/MS of directly diluted biological specimens. The urine sample was subjected to the derivatization protocol without prior glucuronidase and arylsulphatase work-up since 
4-OH-mephedrone was found to decompose completely during this process.

Metamfepramone was chosen as the internal standard due to its availability and structural similarity to the metabolites and due to the fact that it cannot be modified via derivatization conditions. Any urinary matrix effect on the calibration curve was evaluated by analyzing the standards spiked into human urine.

\subsection{Data Acquisition and Analysis}

Blinding: a code (three letters, three digits; e.g. LAU644 for $S$-4-OH-mephedrone) was assigned to the individual stereoisomers of the phase-1 metabolites. Experiments were performed with the identity of the metabolites being masked to the experimenter. Calculations were performed with Micosoft Excel 2010 (Microsoft Corporation, Redmond, WA, USA). Analysis was performed with GraphPad 5.0 (GraphPad Software Inc., La Jolla, CA, USA). Efflux data were analyzed by two-way ANOVA (treatment x time) followed by Bonferroni's test. P values $<0.05$ were considered significant.

\subsection{Materials}

The phase-1 metabolites were synthesized in their enantiopure form. Detailed descriptions of the synthetic procedures and the chemical characterizations are given in the Supporting Information. $\left[{ }^{3} \mathrm{H}\right] \mathrm{MPP}^{+}\left(80-85 \mu \mathrm{Ci} \mathrm{mmol}^{-1}\right)$ was purchased from American Radiolabled Chemicals (St. Louis, MO, USA) and $\left[{ }^{3} \mathrm{H}\right] 5-\mathrm{HT}\left(28.3 \mu \mathrm{CI} \mathrm{mmol}{ }^{-1}\right)$, $\left[{ }^{3} \mathrm{H}\right]$ 8-OH-DPAT, $\left[{ }^{3} \mathrm{H}\right]$ ketanserin, $\left[{ }^{3} \mathrm{H}\right]$ mesulergine, $\left[{ }^{3} \mathrm{H}\right]$ prazosin, $\left[{ }^{3} \mathrm{H}\right]$ rauwolscine, $\mathrm{N}$ methyl- $\left[{ }^{3} \mathrm{H}\right]$ nisoxetine, $\left[{ }^{3} \mathrm{H}\right]$ WIN35,428 and $\left[{ }^{3} \mathrm{H}\right]$ citalopram were purchased from Perkin Elmer (Boston, MA, USA). [ $\left.{ }^{3} \mathrm{H}\right] \mathrm{RO} 5166017$ and R05166017 were provided by F. Hoffmann-La Roche (Basel, Switzerland). All other chemicals were from Sigma-Aldrich (St. Louis, MO, USA). 


\section{Results (643 words)}

\subsection{The stereoisomers of phase-1 metabolites inhibit transporter-mediated uptake}

To test whether each stereoisomer of the metabolites interacts with MATs, we performed uptake inhibition experiments. The stereoisomers of nor-, 4-OH and dihydromephedrone were fully efficacious inhibitors of DAT, NET and SERT mediated uptake (Figure 2). The stereoisomers of nor-mephedrone inhibited DAT and NET with comparable potencies in the low micromolar range, with $\mathrm{IC}_{50}$ values ranging from approximately 3 to $10 \mu \mathrm{M}$. At SERT, $R$-nor-mephedrone was 18 times less potent than $S$ nor-mephedrone, with corresponding IC50 values of 200.0 and $10.9 \mu \mathrm{M}$, respectively. The IC 50 values of $S$ - and $R-4-\mathrm{OH}$-mephedrone to inhibit DAT-mediated uptake were within the same level of potency, i.e. 2.63 and $5.64 \mu \mathrm{M}$, respectively. For NET, the IC 50 values were 9.53 and $18.04 \mu \mathrm{M}$ for $S$ - and $R$-4-OH-mephedrone, respectively. At SERT, $S$ 4-OH-mephedrone ( IC $_{50} 32.1 \mu \mathrm{M}$ ) was a 19 times more potent inhibitor than $R-4-\mathrm{OH}$ mephedrone (IC50 $625.4 \mu \mathrm{M}$ ). The four stereoisomers of dihydro-mephedrone displayed varying potencies as inhibitors at each MAT, with IC $_{50}$ values spanning concentrations from 12 to $216 \mu \mathrm{M}$. The IC 50 values and the corresponding NET/DAT and DAT/SERT ratios are summarized in Table 2 .

\subsection{The stereoisomers of nor-and 4-OH-mephedrone differentially affect SERT-mediated} reverse transport

Nor-, 4-OH- and dihydro-mephedrone act as transportable substrates of MATs (Mayer et al., 2016). We performed release experiments to investigate whether the observed differences between the $R$ - and $S$-enantiomers of nor- and 4-OH-mephedrone on SERTmediated uptake also apply to reverse transport. HEK293 cells stably expressing hSERT were pre-loaded with $\left[{ }^{3} \mathrm{H}\right] 5$-HT and superfused with buffer containing increasing concentrations of test drugs.

Application of two-way ANOVA (concentration $\mathrm{x}$ time) demonstrated that $S$ - $\left(\mathrm{F}_{5.51}=\right.$ 26.71; $P<0.0001)$ and $R$-nor-mephedrone $\left(\mathrm{F}_{5.38}=6.14 ; P=0.0003\right)$ significantly affected the release of tritiated substrate (Figures $3 \mathrm{~A}$ and C). Post hoc tests revealed that 3, 10, 30 and $100 \mu \mathrm{M}$ of $S$-nor-mephedrone significantly elevated reverse transport via SERT versus the vehicle control. For $R$-nor-mephedrone, significant effects were observed at 30 and $100 \mu \mathrm{M}$. Concentrations of $S$-nor-mephedrone exceeding $10 \mu \mathrm{M}$ did not stimulate the release of tritiated 5-HT to a further extent but rather exhibited a trend back 
towards baseline (Figure 3B). This finding is in agreement with earlier observations, demonstrating a biphasic effect of substrate type-releasers on SERT mediated reverse transport (Seidel et al., 2005). S-4-OH-mephedrone significantly affected outwardlydirected transport of $\left[{ }^{3} \mathrm{H}\right] 5-\mathrm{HT}\left(\mathrm{F}_{5.63}=44.74 ; P<0.0001\right)$ (Figure 4A). Post hoc analysis demonstrated significant differences at concentrations of $10 \mu \mathrm{M}$ or higher. No main effect was detected for $R-4-0 H-m e p h e d r o n e\left(F_{5.51}=0.69 ; P=0.63\right)$ ( Figure 4B). Neither $R$-nor-mephedrone nor $S$-4-OH-mephedrone gave rise to bell-shaped concentration response curves (Figures 4C and D); this may indicate that the applied concentrations are non-saturating in our experimental system (Seidel et al., 2005).

\subsection{Monoamine receptor and transporter binding profiles}

Monoamine receptor binding profiles are summarized in Table 3 and Table 4. None of the tested metabolites bound to $5-\mathrm{HT}_{1 \mathrm{~A}}$ or $5-\mathrm{HT}_{2} \mathrm{C}$ receptors, nor did they activate the 5$\mathrm{HT}_{2 \mathrm{~B}}$ receptor. $S$-nor-mephedrone exhibited submicromolar affinities towards rat and mouse TAAR1 ( $\mathrm{K}_{\mathrm{i}}=0.58$ and $0.72 \mu \mathrm{M}$, respectively) and supramicromolar affinities towards human $5-\mathrm{HT}_{2 \mathrm{~A}}\left(\mathrm{~K}_{\mathrm{i}}=7.41 \mu \mathrm{M}\right)$ and $\alpha_{1 \mathrm{~A}}\left(\mathrm{~K}_{\mathrm{i}}=1.33 \mu \mathrm{M}\right)$ receptors. $1 R, 2 R-, 1 S, 2 S$ and $1 R, 2 S$-dihydro-mephedrone bound to rat TAAR1 $\left(\mathrm{K}_{\mathrm{i}}=3.71,3.57\right.$ and $0.56 \mu \mathrm{M}$, respectively), but only $1 S, 2 S$-dihydro-mephedrone interacted with mouse TAAR1 (Ki $=$ $3.85 \mu \mathrm{M})$. However, no human TAAR1 activity was observed in the concentration range investigated $\left(\mathrm{EC}_{50}>30 \mu \mathrm{M}\right) .1 S, 2 S$ - and $1 R, 2 S$-dihydro-mephedrone interacted with 5$\mathrm{HT}_{2 \mathrm{~A}}$ receptors $\left(\mathrm{K}_{\mathrm{i}}=6.66\right.$ and $7.47 \mu \mathrm{M}$, respectively), whereas only $1 R, 2 S$-dihydromephedrone had affinity to the $\alpha_{2 A}$ receptor $\left(K_{i}=1.85 \mu \mathrm{M}\right)$. None of the test drugs bound to MATs with submicromolar affinities. 


\section{Discussion}

The intention of the present study was to investigate the effects of selected phase-1 metabolites of mephedrone in their enantiopure form on monoamine receptors and transporters. Stereospecific pharmacology has been reported for various compounds that target MATs, including cathinone (Hutsell et al., 2016), methcathinone (Sparago et al., 1996), amphetamine (Sitte et al., 1998), MDMA (Rudnick and Wall, 1992) and mephedrone (Gregg et al., 2015; Philogene-Khalid et al., 2017a; Philogene-Khalid et al., 2017b; Vouga et al., 2015). In this study, we found that the stereochemistry affects the pharmacology of the phase-1 metabolites of mephedrone. Each of the stereoisomers tested inhibited MAT-mediated uptake in a concentration dependent manner. In the case of nor-mephedrone, both enantiomers inhibited DAT and NET with comparable potencies. At SERT, however, $S$-nor-mephedrone revealed a pronounced leftward-shift when compared to the $R$-stereoisomer. This observation is consistent with a recent publication (Hutsell et al., 2016), demonstrating that the $R$-enantiomer of normephedrone is less potent than $S$-nor-mephedrone at SERT. Uptake inhibition assays with 4-OH-mephedrone revealed a potency loss from the $S$ - to the $R$-enantiomer at all three MATs. Remarkably, this rightward-shift was again more pronounced at SERT ( $\sim 19$-fold) than at DAT and NET ( $\sim 2$-fold). The four stereoisomers of dihydromephedrone were associated with a more complex pharmacology. The differences in potency were again more pronounced at SERT (up to 10-fold) than at DAT and NET ( 2fold).

A recent study revealed that mephedrone undergoes stereospecific metabolism and the stereoisomers of nor- and 4-OH-mephedrone were detected in biological samples (Castrignano et al., 2017). Based on the differing potencies as inhibitors of SERTmediated uptake, we sought to perform release experiments with the stereoisomers of nor- and 4-OH-mephedrone in SERT-expressing HEK293 cells. Remarkably, only the $S$ enantiomers of nor- and 4-OH-mephedrone acted as fully-fledged releasers at SERT. In the case of $R$-nor-mephedrone, blunted effects on SERT-mediated reverse transport were observed at $100 \mu \mathrm{M}$. R-4-OH-mephedrone failed to cause significant effects over the entire range of concentrations tested ( 1 to $100 \mu \mathrm{M}$ ). It is unlikely that this effect is solely attributable to the reduced potencies as uptake inhibitors: the IC 50 of $R$-normephedrone to inhibit SERT-mediated uptake $(200 \mu \mathrm{M}$, which - following the ChengPrusoff equation - reflects its $\mathrm{K}_{\mathrm{i}}$-value) is only two times higher than the highest concentration applied in release-experiments. Hence, it can be assumed that a 
considerable proportion of transporters will be occupied by $R$-nor-mephedrone at this concentration. According to Seidel and colleagues (Seidel et al., 2005), the maximal effect on reverse-transport elicited by amphetamine-like drugs is expected to occur at concentrations around the corresponding $\mathrm{K}_{\mathrm{i}}$-value of the tested drug. This explanation may not apply to $R-4-\mathrm{OH}$-mephedrone ( $\mathrm{IC}_{50} \sim 625 \mu \mathrm{M}$ ). However, due to limited drug availability, we did not test concentrations higher than $100 \mu \mathrm{M}$. We do not feel that increasing the concentration is necessary, as non-specific, i.e. non-SERT-related, effects may superimpose transporter-mediated tracer fluxes. Furthermore, considering the recreational doses of mephedrone (up to $90 \mathrm{mg}$ nasally and $250 \mathrm{mg}$ orally (Schifano et al., 2011)), it is more than unlikely that $R-4-\mathrm{OH}$-mephedrone builds up at concentrations beyond the ones applied in our experiments. One possible explanation for the observed effects is that the three-dimensional difference between $S$ - and $R$-enantiomers affects their interaction with the binding pocket, thus switching their activity from substrates to non-transportable inhibitors. Interestingly, Hutsell and colleagues (Hutsell et al., 2016) found that both enantiomers of 4-methylcathinone (nor-mephedrone), acted as fully efficacious releasers at SERT in rat brain synaptosomes. This discrepancy may be explained by the fact that we used non-neuronal HEK293 cells as the expression system or differences between the human and rat isoforms of SERT.

Binding of racemic mephedrone to $\alpha_{1 \mathrm{~A}}, \alpha_{2 \mathrm{~A}}, 5-\mathrm{HT}_{2 \mathrm{~A}}$ and $5-\mathrm{HT}_{2 \mathrm{C}}$ receptors has been reported (Luethi et al., 2018a; Simmler et al., 2013) and Philogene-Khalid and colleagues observed that $S$-mephedrone bound to 5-HT2A and 5-HT2C receptors without agonist activity (Philogene-Khalid et al., 2017a).

We found that $S$-nor-mephedrone bound to $\alpha_{1 \mathrm{~A}}$ and 5-HT2A receptors and mouse and rat TAAR1, albeit with moderate affinity towards $5-\mathrm{HT}_{2 \mathrm{~A}}$. Agonistic activity at $\alpha_{1 \mathrm{~A}}$ receptors is implicated in stimulant-induced behaviours, such as locomotor activity (Schmidt and Weinshenker, 2014). For instance, the $\alpha_{1}$ - and $\beta$-adrenergic receptor antagonist carvedilol reduced cardiostimulant and hyperthermic effects of MDMA in humans, but had no effect on subjective effects of the drug (Hysek et al., 2012). The same findings regarding carvedilol on mephedrone-induced hyperthermia were reported in rats (Zona et al., 2016). Activation of 5-HT2A-receptors has previously been demonstrated for mephedrone (Luethi et al., 2018a) and hallucinogens (Rickli et al., 2016). This effect on 5-HT2A receptors may partially contribute to hallucinogenic effects (Kraehenmann et al., 2017; Nichols, 2016) associated with mephedrone (Kasick et al., 2012; Schifano et al., 2011). Binding to TAAR1 exerts auto-inhibitory effects on monoamine releasing 
neurons (Revel et al., 2011; Revel et al., 2012), which has been linked to neuroprotective effects (Di Cara et al., 2011; Lindemann et al., 2008; Revel et al., 2012). Interestingly, binding to rat TAAR1 has been reported for MDMA and mephedrone, with MDMA displaying higher affinities than mephedrone (Simmler et al., 2013). However, in contrast to MDMA, systemic administration of mephedrone did not deplete the 5-HT content in striatum and cortex (Baumann et al., 2012). This observation may be explained by different activities of both drugs at the vesicular monoamine transporter 2 (Cozzi et al., 1999; Pifl et al., 2015). However, this finding also indicates that the exact role of TAAR1 in psychostimulant action remains unclear (Sitte and Freissmuth, 2015). $(1 S, 2 S)$-dihydro-mephedrone bound to mouse TAAR1, but not to rat TAAR1. In contrast, $(1 R, 2 R)-,(1 R, 2 S)$ - and $(1 S, 2 R)$-dihydro-mephedrone bound to rat TAAR1 but not to mouse TAAR1. $(1 S, 2 S)$ - and $(1 R, 2 S)$-dihydro-mephedrone also bound to $5-\mathrm{HT}_{2 \mathrm{~A}^{-}}$ receptors and the latter was also found to bind to $\alpha_{2 \mathrm{~A}}$ receptors. Overall, the binding data suggest that some of the effects of mephedrone may be shaped - at least in part by the activities of the metabolites at a subset of monoamine receptors.

In addition to our own in vitro studies, we performed a pilot chiral analysis of a urine sample obtained from a human mephedrone user (Figure 5). 4-OH-mephedrone was found to be problematic in our assays based on the partial racemization of $S$ - and $R$ enantiomers under assay conditions, consequently affecting calibration curves and compound determination in the analysis. Given the limited stability of this metabolite and its lower abundance in the urine sample compared to nor-mephedrone, we refrained from drawing further conclusions for this metabolite.

In the case of nor-mephedrone we found that the $S$ - enantiomer is almost 2 times more abundant in the human urine sample compared to its $R$ - counterpart; hence, normephedrone is predominantly excreted in its $S$-enantiomeric form. This novel finding is in excellent agreement with a recent report (Castrignano et al., 2017). Previously, we found that systemically administered nor-mephedrone exerts profound effects on extracellular serotonin, whereas the effects were less pronounced for dopamine (Mayer et al., 2016). According to drug user reports, the subjective effects of mephedrone resemble those of MDMA, which markedly affects the serotonergic system (Green et al., 2014; Schifano et al., 2011). Given the pharmacological profile of mephedrone, i.e. no selectivity for SERT (Baumann et al., 2012), it is tempting to speculate that some of the subjective effects are linked to $S$-nor-mephedrone. This interpretation is bolstered by the fact that $R$-mephedrone appears to be the predominant stereoisomer in human 
samples and waste water (Castrignano et al., 2017). $R$-mephedrone shows greater selectivity for DAT over SERT than $S$-mephedrone. In line with this finding, only $R$ mephedrone induced conditioned place preference (CPP). Furthermore, although both enantiomers facilitated intracranial self-stimulation (ICSS), $R$-mephedrone did so to a greater extent (Gregg et al., 2015). ICSS and CPP positively correlate with the rewarding effects of psychostimulants, which appear to be defined by the relative DAT/SERT selectivity of drugs (Roberts et al., 1999). Considering the higher DAT/SERT ratio of $R$ mephedrone and its relative abundance in humans when compared to $S$-mephedrone, this feature provides a potential explanation for the re-dosing of mephedrone within sessions (Jones et al., 2016). The pharmacological profiles of $R$-mephedrone and $S$ mephedrone led Philogene-Khalid and colleagues to conclude that the rewarding effects of mephedrone are primarily due to the actions of $R$-mephedrone (Philogene-Khalid et al., 2017a). The same authors found that $S$-mephedrone reduces anxiety and depressionlike effects in rats that were withdrawn from cocaine or MDPV. Possibly, due to the increased SERT/DAT ratio of $S$-mephedrone, administration of this drug adequately compensates for deficits in extracellular 5-HT, which are associated with cocaine withdrawal (Parsons et al., 1995, 1996). The increased SERT selectivity of $S$-normephedrone may contribute to the entactogenic effects of mephedrone (Papaseit et al., 2017).

CYP2D6 has been demonstrated to be the main enzyme involved in the metabolism of mephedrone (Pedersen et al., 2013). Cytochrome P450 enzymes (CYPs) are abundantly expressed in the liver. However, it has been demonstrated that the expression of CYPs is not confined to the liver and various CYP isoforms have been detected in the nervous system (Ferguson and Tyndale, 2011; Miksys and Tyndale, 2002). CYP2D6 is expressed in numerous regions of the human brain (Siegle et al., 2001), including hippocampus and striatum (Chinta et al., 2002). Importantly, a recent in vivo study provided evidence that CYPs contribute to metabolic processes in the brain (Bromek et al., 2011). Hence, it is tempting to assume that the metabolites can be formed in situ and gain access to MATs and monoamine receptors, and shape the overall effects of mephedrone. In addition, hepatically formed nor-mephedrone crosses the blood brain barrier, as evidenced by its effects on extracellular 5-HT and dopamine in the nucleus accumbens upon systemic administration. This might be attributed to its distribution coefficient $(\log D=1.29$ ) (Mayer et al., 2016) as the lipid solubility and size of a substance correlates 
with its likelihood to enter the brain (van Bree et al., 1988; Waterhouse, 2003) or transport processes that have yet to be determined.

The ability to induce reverse-transport via SERT is essential to the action of MDMA, since most of the subjective effects of MDMA were attenuated by co-administration of the SERT-inhibitor citalopram (Liechti et al., 2000). This observation further supports the hypothesis that $S$-nor-mephedrone contributes to the action of mephedrone as $R$ nor-mephedrone failed to induce release via human SERT. Aside from the effects at SERT, stereoselectivity at NET may also affect the pharmacology of mephedrone. Administration of the NET-inhibitor reboxetine not only reduced the effects of MDMA on heart rate and blood pressure, but also attenuated "drug-liking" and "good drug-effects" (Hysek et al., 2011). Olesti et al. (Olesti et al., 2017) recently published a study on the pharmacokinetics of mephedrone and its metabolites in human plasma and urine. In addition, this study quantified mephedrone and a subset of metabolites in rat prefrontal cortex after systemic administration of the parental substance.

4'carboxy-mephedrone (COOH-mephedrone, which is derived from 4-OH-mephedrone) and nor-mephedrone were the most abundant metabolites in human plasma with $\mathrm{AUC}_{0}$ $8 \mathrm{~h}$ levels of $113 \%$ and $46 \%$, respectively, of those of mephedrone after ingestion of 150 mg of mephedrone ( $\mathrm{n}=6$ individuals). Other minor metabolites detected were $N$ succinyl-nor-mephedrone (SUCC-mephedrone) (4\%) and dihydro-mephedrone (11\%). The half-life of mephedrone was $2.2 \mathrm{~h}$, compared to $4.5 \mathrm{~h}$ (nor-mephedrone), $8.2 \mathrm{~h}$ (SUCC-mephedrone) $5.7 \mathrm{~h}$ (DIHYDRO-mephedrone) and $1.9 \mathrm{~h}$ (COHH-mephedrone). Moreover, $1 \mathrm{~h}$ after administration of mephedrone (30 mg/kg; i.p.), the concentration of nor-mephedrone in rat prefrontal cortex exceeded the concentration of the parental drug by $100 \%$, with $\mathrm{COOH}$-mephedrone and SUCC-mephedrone being detectable in small amounts. In the same study, the authors observed $C_{\max }$ values of $179 \pm 29.3$ and $54.4 \pm 4.9$ (ng/mL, \pm SEM) for mephedrone and nor-mephedrone, respectively. Considering the moderate dose (150 mg) used in this study, the brain concentrations can be expected to be in the low micromolar range after the use of moderate to high doses. These findings strengthen the hypothesis that the effects of mephedrone may be partially shaped by its metabolites, with an emphasis on nor-mephedrone. The limitations of this study are that we did not test conjugated metabolites for their activities at monoamine receptors and transporters and that limited information is available on the abundance of the metabolites in human brain. 
Hence, further studies are warranted to unravel the pharmacokinetics of the metabolites in a time-resolved and stereospecific manner to clarify the overall contribution of the metabolites to the effects of mephedrone on neurochemistry and behavior. 
Table 2: Effect of test drugs on monoamine transporter mediated uptake.

\begin{tabular}{|c|c|c|c|c|c|}
\hline \multicolumn{6}{|c|}{ IC50 $(\mu \mathrm{M})(95 \% \mathrm{CI}$ in brackets $)$} \\
\hline & DAT & NET & SERT & $\begin{array}{c}\text { NET/DAT } \\
\text { ratio }\end{array}$ & $\begin{array}{c}\text { DAT/SERT } \\
\text { ratio }\end{array}$ \\
\hline $\begin{array}{c}S \text {-nor- } \\
\text { mephedrone }\end{array}$ & $\begin{array}{c}8.72 \\
\text { (5.9 to } 12.87)\end{array}$ & $\begin{array}{c}3.84 \\
(3.16 \text { to } 4.66)\end{array}$ & $\begin{array}{c}10.88 \\
\text { (6.33 to } 18.7)\end{array}$ & 2.27 & 1.25 \\
\hline $\begin{array}{c}R \text {-nor- } \\
\text { mephedrone }\end{array}$ & $\begin{array}{c}9.44 \\
(6.51 \text { to } 13.68)\end{array}$ & $\begin{array}{c}4.54 \\
(3.44 \text { to } 5.99)\end{array}$ & $\begin{array}{c}200.0 \\
(106.8 \text { to } 374.6)\end{array}$ & 2,08 & 21.19 \\
\hline $\begin{array}{c}S-4-\mathrm{OH}- \\
\text { mephedrone }\end{array}$ & $\begin{array}{c}2.63 \\
(1.98 \text { to } 3.49)\end{array}$ & $\begin{array}{c}9.53 \\
(7.49 \text { to } 12.14)\end{array}$ & $\begin{array}{c}32.05 \\
(24.39 \text { to } 42.13)\end{array}$ & 0.28 & 12.19 \\
\hline $\begin{array}{c}R \text {-4-OH- } \\
\text { mephedrone }\end{array}$ & $\begin{array}{c}5.64 \\
(3.68 \text { to } 8.64)\end{array}$ & $\begin{array}{c}18.04 \\
(11.76 \text { to } 27.67)\end{array}$ & $\begin{array}{c}625.4 \\
(478 \text { to } 818.3)\end{array}$ & 0.31 & 110.89 \\
\hline $\begin{array}{c}1 S, 2 R \text { Dihydro- } \\
\text { mephedrone }\end{array}$ & $\begin{array}{c}12.67 \\
(10.41 \text { to } \\
15.41)\end{array}$ & $\begin{array}{c}22.66 \\
(18.62 \text { to } 27.57)\end{array}$ & $\begin{array}{c}65.55 \\
\text { (40.15 to } 107)\end{array}$ & 0.56 & 5.17 \\
\hline $\begin{array}{c}1 R, 2 S \text { Dihydro- } \\
\text { mephedrone }\end{array}$ & $\begin{array}{c}21.11 \\
(17.21 \text { to } \\
25.88)\end{array}$ & $\begin{array}{c}38.99 \\
(33.45 \text { to } 45.44)\end{array}$ & $\begin{array}{c}32.21 \\
\text { (26.72 to } 38.84)\end{array}$ & 0.54 & 1.53 \\
\hline $\begin{array}{c}1 R, 2 R \text { Dihydro- } \\
\text { mephedrone }\end{array}$ & $\begin{array}{c}14.12 \\
(9.43 \text { to } 21.15)\end{array}$ & $\begin{array}{c}39.05 \\
(27.12 \text { to } 56.21)\end{array}$ & $\begin{array}{c}302.3 \\
(228.4 \text { to } 400.1)\end{array}$ & 0.36 & 21.41 \\
\hline $\begin{array}{c}1 S, 2 S \text { Dihydro- } \\
\text { mephedrone }\end{array}$ & $\begin{array}{c}12.89 \\
(10.12 \text { to } \\
16.44)\end{array}$ & $\begin{array}{c}47.09 \\
(27.83 \text { to } 79.67)\end{array}$ & $\begin{array}{c}248.2 \\
\text { (220.8 to } 279)\end{array}$ & 0.27 & 19.26 \\
\hline
\end{tabular}

Data are shown as the mean (95\% CI in parenthesis), obtained from non-linear regression fits as shown in Figure 2. NET/DAT ratio = 1/NET IC 50 divided by $1 /$ DAT IC $_{50}$.

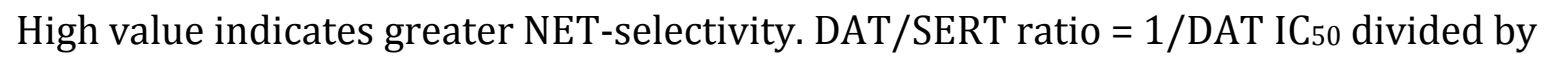
1/SERT IC50. High value indicates greater DAT selectivity. 
Table 3: Monoamine receptor binding profiles. Binding profiles were obtained as described in "materials and methods". $\mathrm{K}_{\mathrm{i}}$ and $\mathrm{EC}_{50}$ values $(\mu \mathrm{M})$ are given as mean and SD from 3 independent measurements.

\begin{tabular}{|c|c|c|c|c|c|c|c|c|c|}
\hline & $\begin{array}{l}\text { Human } \\
\text { TAAR1 }\end{array}$ & $\begin{array}{c}\text { Rat } \\
\text { TAAR1 }\end{array}$ & $\begin{array}{l}\text { Mouse } \\
\text { TAAR1 }\end{array}$ & $5 \mathrm{HT}_{1 \mathrm{~A}}$ & $5 \mathrm{HT}_{2 \mathrm{~A}}$ & $5 \mathrm{HT}_{2 \mathrm{~B}}$ & $5 \mathrm{HT}_{2 \mathrm{C}}$ & $\alpha_{1 \mathrm{~A}}$ & $\alpha_{2 \mathrm{~A}}$ \\
\hline & $\begin{array}{c}\mathrm{EC}_{50} \pm \\
\mathrm{SD} \\
{[\mu \mathrm{M}]}\end{array}$ & $\begin{array}{c}\mathrm{K}_{\mathrm{i}} \pm \mathrm{SD} \\
{[\mu \mathrm{M}]}\end{array}$ & $\begin{array}{c}\mathrm{K}_{\mathrm{i}} \pm \mathrm{SD} \\
{[\mu \mathrm{M}]}\end{array}$ & $\begin{array}{c}\mathrm{K}_{\mathrm{i}} \pm \\
\mathrm{SD} \\
{[\mu \mathrm{M}]}\end{array}$ & $\begin{array}{c}\mathrm{K}_{\mathrm{i}} \pm \mathrm{SD} \\
{[\mu \mathrm{M}]}\end{array}$ & $\begin{array}{c}\mathrm{EC}_{50} \pm \\
\mathrm{SD} \\
{[\mu \mathrm{M}]}\end{array}$ & $\begin{array}{c}\mathrm{K}_{\mathrm{i}} \pm \\
\mathrm{SD} \\
{[\mu \mathrm{M}]}\end{array}$ & $\begin{array}{c}\mathrm{K}_{\mathrm{i}} \pm \\
\mathrm{SD} \\
{[\mu \mathrm{M}]}\end{array}$ & $\begin{array}{c}\mathrm{K}_{\mathrm{i}} \pm \mathrm{SD} \\
{[\mu \mathrm{M}]}\end{array}$ \\
\hline $\begin{array}{c}S \text {-nor- } \\
\text { mephedron } \\
\mathrm{e}\end{array}$ & $>30$ & $\begin{array}{c}0.5873 \pm \\
0.02\end{array}$ & $\begin{array}{c}0.725 \pm \\
0.026\end{array}$ & $>17$ & $\begin{array}{c}7.41 \\
\pm 0.305\end{array}$ & $>10$ & $>5$ & $\begin{array}{c}1.33 \\
\pm 0.051\end{array}$ & $>4.6$ \\
\hline $\begin{array}{c}R \text {-nor- } \\
\text { mephedron } \\
\mathrm{e}\end{array}$ & n.d. & $>5.19$ & $>4.36$ & $\begin{array}{c}>17.5 \\
9\end{array}$ & $>12.98$ & $>10$ & $>5.07$ & $>2.24$ & $>4.68$ \\
\hline $\begin{array}{c}S-4-\mathrm{OH}- \\
\text { mephedron } \\
\mathrm{e}\end{array}$ & n.d. & $>5.19$ & $>4.36$ & $\begin{array}{c}>17.5 \\
9\end{array}$ & $>12.98$ & $>10$ & $>5.07$ & $>2.24$ & $>4.68$ \\
\hline $\begin{array}{c}R-4-\mathrm{OH}- \\
\text { mephedron } \\
\mathrm{e}\end{array}$ & n.d. & $>5.19$ & $>4.36$ & $\begin{array}{c}>17.5 \\
9\end{array}$ & $>12.98$ & $>10$ & $>5.07$ & $>2.24$ & $>4.68$ \\
\hline $\begin{array}{l}(1 R, 2 R)- \\
\text { dihydro- } \\
\text { mephedron } \\
\text { e }\end{array}$ & n.d. & $\begin{array}{c}3.71 \\
\pm 0.53\end{array}$ & $>4.36$ & $\begin{array}{c}>17.5 \\
9\end{array}$ & $>12.98$ & $>10$ & $>5.07$ & $>2.24$ & $>4.68$ \\
\hline $\begin{array}{c}(1 S, 2 S)- \\
\text { dihydro- } \\
\text { mephedron } \\
\text { e }\end{array}$ & n.d. & $>5.19$ & $\begin{array}{c}3.85 \\
\pm 0.39\end{array}$ & $\begin{array}{c}>17.5 \\
9\end{array}$ & $\begin{array}{r}6.665 \\
\pm 2.36\end{array}$ & $>10$ & $>5.07$ & $>2.24$ & $>4.68$ \\
\hline $\begin{array}{l}(1 S, 2 R)- \\
\text { dihydro- } \\
\text { mephedron } \\
\text { e }\end{array}$ & n.d. & $\begin{array}{c}3.568 \pm 0 \\
19\end{array}$ & $>4.36$ & $\begin{array}{c}>17.5 \\
9\end{array}$ & $>12.98$ & $>10$ & $>5.07$ & $>2.24$ & $>4.68$ \\
\hline $\begin{array}{l}(1 R, 2 S)- \\
\text { dihydro- } \\
\text { mephedron } \\
\text { e }\end{array}$ & $>30$ & $\begin{array}{c}0.558 \pm 0 \\
049\end{array}$ & $>4.36$ & $\begin{array}{c}>17.5 \\
9\end{array}$ & $\begin{array}{c}7.476 \pm 2.1 \\
26\end{array}$ & $>10$ & $>5.07$ & $>2.24$ & $\begin{array}{c}1.846 \pm 0 . \\
388\end{array}$ \\
\hline
\end{tabular}


Table 4: Monoamine transporter binding profiles. Binding profiles were obtained as described in "materials and methods". $\mathrm{K}_{\mathrm{i}}$ values $[\mu \mathrm{M}]$ are given as mean and SD from 3 independent measurements.

\begin{tabular}{|l|l|l|l|}
\hline & $\mathrm{DAT}$ & $\mathrm{NET}$ & $\mathrm{SERT}$ \\
\hline & $\mathrm{K}_{\mathrm{i}} \pm \mathrm{SD}[\mu \mathrm{M}]$ & $\mathrm{K}_{\mathrm{i}} \pm \mathrm{SD}[\mu \mathrm{M}]$ & $\mathrm{K}_{\mathrm{i}} \pm \mathrm{SD}[\mu \mathrm{M}]$ \\
\hline$S$-nor-mephedrone & $>8.52$ & $>8.77$ & $>7.42$ \\
\hline$R$-nor-mephedrone & $>8.52$ & $>8.77$ & $>7.42$ \\
\hline$S$-4-OH-mephedrone & $6.69 \pm 1.54$ & $>8.77$ & $>7.42$ \\
\hline$R$-4-OH-mephedrone & $>8.52$ & $>8.77$ & $>7.42$ \\
\hline$(1 R, 2 R)$-dihydro-mephedrone & $6.07 \pm 0.11$ & $>8.77$ & $>7.42$ \\
\hline$(1 S, 2 S)$-dihydro-mephedrone & $>8.52$ & $>8.77$ & $>7.42$ \\
\hline$(1 S, 2 R)$-dihydro-mephedrone & $>8.52$ & $>8.77$ & $>7.42$ \\
\hline$(1 R, 2 S)$-dihydro-mephedrone & $>8.52$ & $>8.77$ & $>7.42$ \\
\hline
\end{tabular}


Competing interests: H.H.S. has received honoraria for lectures and consulting from AbbVie, Aesca, Amgen, Astellas, AstraZeneca, Astropharma, Chiesi, Gebro, IMH, IIR, Janssen-Cilag, Lundbeck, MSD, Mundipharma, Pfizer, Ratiopharm, Roche, Sandoz, SanofiAventis, Shire, Serumwerk Bernburg, Vertex (past 5 years). All other authors declare no conflicts of interest.

Author contributions: F.P.M., D.C., D.A.P., L.W., D.L., M.H., K.J., T.S., and M.C.H. performed experiments. F.P.M., G.M., M.C.H., M.E.L., M.D.M. and H.H.S. designed the experiments. F.P.M. and H.H.S. wrote the manuscript and received significant input from all other authors.

Funding: This work was supported by the Austrian Research Fund/FWF grants F3506 (H.H.S.) and W1232 (H.H.S., M.D.M.), Federal Office of Public Health grant 16.921318 (M.E.L.), and the Austrian Academy of Sciences (DOC-fellowship 2014-2016, F.P.M.). 


\section{References}

Archer, J. R., Dargan, P. I., Hudson, S., Wood, D. M., 2013. Analysis of anonymous pooled urine from portable urinals in central London confirms the significant use of novel psychoactive substances. QJM 106, 147-152.

Archer, J. R., Dargan, P. I., Lee, H. M., Hudson, S., Wood, D. M., 2014. Trend analysis of anonymised pooled urine from portable street urinals in central London identifies variation in the use of novel psychoactive substances. Clin Toxicol (Phila) 52, 160-165. Baumann, M. H., Ayestas, M. A., Jr., Partilla, J. S., Sink, J. R., Shulgin, A. T., Daley, P. F., Brandt, S. D., Rothman, R. B., Ruoho, A. E., Cozzi, N. V., 2012. The designer methcathinone analogs, mephedrone and methylone, are substrates for monoamine transporters in brain tissue. Neuropsychopharmacology 37, 1192-1203.

Baumann, M. H., Volkow, N. D., 2016. Abuse of New Psychoactive Substances: Threats and Solutions. Neuropsychopharmacology 41, 663-665.

Brandt, S. D., King, L. A., Evans-Brown, M., 2014. The new drug phenomenon. Drug Test Anal 6, 587-597.

Bromek, E., Haduch, A., Golembiowska, K., Daniel, W. A., 2011. Cytochrome P450 mediates dopamine formation in the brain in vivo. J Neurochem 118, 806-815. Castiglioni, S., Borsotti, A., Senta, I., Zuccato, E., 2015. Wastewater analysis to monitor spatial and temporal patterns of use of two synthetic recreational drugs, ketamine and mephedrone, in Italy. Environ Sci Technol 49, 5563-5570.

Castrignano, E., Mardal, M., Rydevik, A., Miserez, B., Ramsey, J., Shine, T., Pantos, G. D., Meyer, M. R., Kasprzyk-Hordern, B., 2017. A new approach towards biomarker selection in estimation of human exposure to chiral chemicals: a case study of mephedrone. Sci Rep 7, 13009.

Chinta, S. J., Pai, H. V., Upadhya, S. C., Boyd, M. R., Ravindranath, V., 2002. Constitutive expression and localization of the major drug metabolizing enzyme, cytochrome P4502D in human brain. Brain Res Mol Brain Res 103, 49-61.

Cozzi, N. V., Sievert, M. K., Shulgin, A. T., Jacob, P., 3rd, Ruoho, A. E., 1999. Inhibition of plasma membrane monoamine transporters by beta-ketoamphetamines. Eur J Pharmacol 381, 63-69.

Di Cara, B., Maggio, R., Aloisi, G., Rivet, J. M., Lundius, E. G., Yoshitake, T., Svenningsson, P., Brocco, M., Gobert, A., De Groote, L., Cistarelli, L., Veiga, S., De Montrion, C., Rodriguez, M., Galizzi, J. P., Lockhart, B. P., Coge, F., Boutin, J. A., Vayer, P., Verdouw, P. M., Groenink, L., Millan, M. J., 2011. Genetic deletion of trace amine 1 receptors reveals their role in autoinhibiting the actions of ecstasy (MDMA). J Neurosci 31, 16928-16940.

Eshleman, A. J., Wolfrum, K. M., Hatfield, M. G., Johnson, R. A., Murphy, K. V., Janowsky, A., 2013. Substituted methcathinones differ in transporter and receptor interactions.

Biochem Pharmacol 85, 1803-1815.

Ferguson, C. S., Tyndale, R. F., 2011. Cytochrome P450 enzymes in the brain: emerging evidence of biological significance. Trends Pharmacol Sci 32, 708-714.

Green, A. R., King, M. V., Shortall, S. E., Fone, K. C., 2014. The preclinical pharmacology of mephedrone; not just MDMA by another name. Br J Pharmacol 171, 2251-2268.

Gregg, R. A., Baumann, M. H., Partilla, J. S., Bonano, J. S., Vouga, A., Tallarida, C. S., Velvadapu, V., Smith, G. R., Peet, M. M., Reitz, A. B., Negus, S. S., Rawls, S. M., 2015. Stereochemistry of mephedrone neuropharmacology: enantiomer-specific behavioural and neurochemical effects in rats. Br J Pharmacol 172, 883-894.

Hadlock, G. C., Webb, K. M., McFadden, L. M., Chu, P. W., Ellis, J. D., Allen, S. C., Andrenyak, D. M., Vieira-Brock, P. L., German, C. L., Conrad, K. M., Hoonakker, A. J., Gibb, J. W., Wilkins, D. G., Hanson, G. R., Fleckenstein, A. E., 2011. 4-Methylmethcathinone 
(mephedrone): neuropharmacological effects of a designer stimulant of abuse. J Pharmacol Exp Ther 339, 530-536.

Hockenhull, J., Murphy, K. G., Paterson, S., 2016. Mephedrone use is increasing in London. Lancet 387, 1719-1720.

Hutsell, B. A., Baumann, M. H., Partilla, J. S., Banks, M. L., Vekariya, R., Glennon, R. A., Negus, S. S., 2016. Abuse-related neurochemical and behavioral effects of cathinone and 4-methylcathinone stereoisomers in rats. Eur Neuropsychopharmacol 26, 288-297.

Hysek, C., Schmid, Y., Rickli, A., Simmler, L. D., Donzelli, M., Grouzmann, E., Liechti, M. E., 2012. Carvedilol inhibits the cardiostimulant and thermogenic effects of MDMA in humans. Br J Pharmacol 166, 2277-2288.

Hysek, C. M., Simmler, L. D., Ineichen, M., Grouzmann, E., Hoener, M. C., Brenneisen, R., Huwyler, J., Liechti, M. E., 2011. The norepinephrine transporter inhibitor reboxetine reduces stimulant effects of MDMA ("ecstasy") in humans. Clin Pharmacol Ther 90, 246255.

Jones, L., Reed, P., Parrott, A., 2016. Mephedrone and 3,4-methylenedioxymethamphetamine: Comparative psychobiological effects as reported by recreational polydrug users. J Psychopharmacol 30, 1313-1320.

Kasick, D. P., McKnight, C. A., Klisovic, E., 2012. "Bath salt" ingestion leading to severe intoxication delirium: two cases and a brief review of the emergence of mephedrone use. Am J Drug Alcohol Abuse 38, 176-180.

Kehr, J., Ichinose, F., Yoshitake, S., Goiny, M., Sievertsson, T., Nyberg, F., Yoshitake, T., 2011. Mephedrone, compared with MDMA (ecstasy) and amphetamine, rapidly increases both dopamine and 5-HT levels in nucleus accumbens of awake rats. $\mathrm{Br} \mathrm{J}$ Pharmacol 164, 1949-1958.

Kelly, J. P., 2011. Cathinone derivatives: a review of their chemistry, pharmacology and toxicology. Drug Test Anal 3, 439-453.

Kraehenmann, R., Pokorny, D., Vollenweider, L., Preller, K. H., Pokorny, T., Seifritz, E., Vollenweider, F. X., 2017. Dreamlike effects of LSD on waking imagery in humans depend on serotonin 2A receptor activation. Psychopharmacology (Berl) 234, 20312046.

Kristensen, A. S., Andersen, J., Jorgensen, T. N., Sorensen, L., Eriksen, J., Loland, C. J., Stromgaard, K., Gether, U., 2011. SLC6 neurotransmitter transporters: structure, function, and regulation. Pharmacol Rev 63, 585-640.

Liechti, M. E., Baumann, C., Gamma, A., Vollenweider, F. X., 2000. Acute psychological effects of 3,4-methylenedioxymethamphetamine (MDMA, "Ecstasy") are attenuated by the serotonin uptake inhibitor citalopram. Neuropsychopharmacology 22, 513-521.

Lindemann, L., Meyer, C. A., Jeanneau, K., Bradaia, A., Ozmen, L., Bluethmann, H., Bettler, B., Wettstein, J. G., Borroni, E., Moreau, J. L., Hoener, M. C., 2008. Trace amine-associated receptor 1 modulates dopaminergic activity. J Pharmacol Exp Ther 324, 948-956.

Luethi, D., Kolaczynska, K. E., Docci, L., Krahenbuhl, S., Hoener, M. C., Liechti, M. E., 2018a. Pharmacological profile of mephedrone analogs and related new psychoactive substances. Neuropharmacology, 4-12.

Luethi, D., Trachsel, D., Hoener, M. C., Liechti, M. E., 2018b. Monoamine receptor interaction profiles of 4-thio-substituted phenethylamines (2C-T drugs).

Neuropharmacology 134, 141-148.

Martinez-Clemente, J., Escubedo, E., Pubill, D., Camarasa, J., 2012. Interaction of mephedrone with dopamine and serotonin targets in rats. Eur Neuropsychopharmacol 22, 231-236.

Mayer, F. P., Luf, A., Nagy, C., Holy, M., Schmid, R., Freissmuth, M., Sitte, H. H., 2017. Application of a Combined Approach to Identify New Psychoactive Street Drugs and 
Decipher Their Mechanisms at Monoamine Transporters. Curr Top Behav Neurosci 32, 333-350.

Mayer, F. P., Wimmer, L., Dillon-Carter, O., Partilla, J. S., Burchardt, N. V., Mihovilovic, M. D., Baumann, M. H., Sitte, H. H., 2016. Phase I metabolites of mephedrone display

biological activity as substrates at monoamine transporters. Br J Pharmacol 173, 2657 2668.

Miksys, S. L., Tyndale, R. F., 2002. Drug-metabolizing cytochrome P450s in the brain. J Psychiatry Neurosci 27, 406-415.

Mohr, S., Weiss, J. A., Spreitz, J., Schmid, M. G., 2012. Chiral separation of new cathinoneand amphetamine-related designer drugs by gas chromatography-mass spectrometry using trifluoroacetyl-l-prolyl chloride as chiral derivatization reagent. J Chromatogr A 1269, 352-359.

Murnane, K. S., Fantegrossi, W. E., Godfrey, J. R., Banks, M. L., Howell, L. L., 2010.

Endocrine and neurochemical effects of 3,4-methylenedioxymethamphetamine and its stereoisomers in rhesus monkeys. J Pharmacol Exp Ther 334, 642-650.

Nichols, D. E., 2016. Psychedelics. Pharmacol Rev 68, 264-355.

Olesti, E., Farre, M., Papaseit, E., Krotonoulas, A., Pujadas, M., de la Torre, R., Pozo, O. J., 2017. Pharmacokinetics of Mephedrone and Its Metabolites in Human by LC-MS/MS. AAPS J 19, 1767-1778.

Ordak, M., Nasierowski, T., Muszynska, E., 2018. The growing problem of mephedrone use in Warsaw, Poland, 2010-18. Lancet Psychiatry 5, 787.

Papaseit, E., Molto, J., Muga, R., Torrens, M., de la Torre, R., Farre, M., 2017. Clinical Pharmacology of the Synthetic Cathinone Mephedrone. Curr Top Behav Neurosci 32, 313-331.

Parsons, L. H., Koob, G. F., Weiss, F., 1995. Serotonin dysfunction in the nucleus accumbens of rats during withdrawal after unlimited access to intravenous cocaine. J Pharmacol Exp Ther 274, 1182-1191.

Parsons, L. H., Koob, G. F., Weiss, F., 1996. Extracellular serotonin is decreased in the nucleus accumbens during withdrawal from cocaine self-administration. Behav Brain Res 73, 225-228.

Pedersen, A. J., Reitzel, L. A., Johansen, S. S., Linnet, K., 2013. In vitro metabolism studies on mephedrone and analysis of forensic cases. Drug Test Anal 5, 430-438.

Philogene-Khalid, H. L., Hicks, C., Reitz, A. B., Liu-Chen, L. Y., Rawls, S. M., 2017a. Synthetic cathinones and stereochemistry: $S$ enantiomer of mephedrone reduces anxiety- and depressant-like effects in cocaine- or MDPV-abstinent rats. Drug Alcohol Depend 178, 119-125.

Philogene-Khalid, H. L., Simmons, S. J., Nayak, S., Martorana, R. M., Su, S. H., Caro, Y., Ranieri, B., DiFurio, K., Mo, L., Gentile, T. A., Murad, A., Reitz, A. B., Muschamp, J. W., Rawls, S. M., 2017b. Stereoselective Differences between the Reinforcing and Motivational Effects of Cathinone-Derived 4-Methylmethcathinone (Mephedrone) In Self-Administering Rats. ACS Chem Neurosci.

Pifl, C., Reither, H., Hornykiewicz, O., 2015. The profile of mephedrone on human monoamine transporters differs from 3,4-methylenedioxymethamphetamine primarily by lower potency at the vesicular monoamine transporter. Eur J Pharmacol 755, 119126.

Revel, F. G., Moreau, J. L., Gainetdinov, R. R., Bradaia, A., Sotnikova, T. D., Mory, R., Durkin, S., Zbinden, K. G., Norcross, R., Meyer, C. A., Metzler, V., Chaboz, S., Ozmen, L., Trube, G., Pouzet, B., Bettler, B., Caron, M. G., Wettstein, J. G., Hoener, M. C., 2011. TAAR1 activation modulates monoaminergic neurotransmission, preventing hyperdopaminergic and hypoglutamatergic activity. Proc Natl Acad Sci U S A 108, 8485-8490. 
Revel, F. G., Moreau, J. L., Gainetdinov, R. R., Ferragud, A., Velazquez-Sanchez, C., Sotnikova, T. D., Morairty, S. R., Harmeier, A., Groebke Zbinden, K., Norcross, R. D., Bradaia, A., Kilduff, T. S., Biemans, B., Pouzet, B., Caron, M. G., Canales, J. J., Wallace, T. L., Wettstein, J. G., Hoener, M. C., 2012. Trace amine-associated receptor 1 partial agonism reveals novel paradigm for neuropsychiatric therapeutics. Biol Psychiatry 72, 934-942. Rickli, A., Moning, O. D., Hoener, M. C., Liechti, M. E., 2016. Receptor interaction profiles of novel psychoactive tryptamines compared with classic hallucinogens. Eur Neuropsychopharmacol 26, 1327-1337.

Roberts, D. C., Phelan, R., Hodges, L. M., Hodges, M. M., Bennett, B., Childers, S., Davies, H., 1999. Self-administration of cocaine analogs by rats. Psychopharmacology (Berl) 144, 389-397.

Rudnick, G., Wall, S. C., 1992. The molecular mechanism of "ecstasy" [3,4methylenedioxy-methamphetamine (MDMA)]: serotonin transporters are targets for MDMA-induced serotonin release. Proc Natl Acad Sci U S A 89, 1817-1821.

Salomone, A., Gazzilli, G., Di Corcia, D., Gerace, E., Vincenti, M., 2016. Determination of cathinones and other stimulant, psychedelic, and dissociative designer drugs in real hair samples. Anal Bioanal Chem 408, 2035-2042.

Schifano, F., Albanese, A., Fergus, S., Stair, J. L., Deluca, P., Corazza, O., Davey, Z., Corkery, J., Siemann, H., Scherbaum, N., Farre, M., Torrens, M., Demetrovics, Z., Ghodse, A. H., Psychonaut Web, M., Re, D. R. G., 2011. Mephedrone (4-methylmethcathinone; 'meow meow'): chemical, pharmacological and clinical issues. Psychopharmacology (Berl) 214, 593-602.

Schmidt, K. T., Weinshenker, D., 2014. Adrenaline rush: the role of adrenergic receptors in stimulant-induced behaviors. Mol Pharmacol 85, 640-650.

Seidel, S., Singer, E. A., Just, H., Farhan, H., Scholze, P., Kudlacek, O., Holy, M., Koppatz, K., Krivanek, P., Freissmuth, M., Sitte, H. H., 2005. Amphetamines take two to tango: an oligomer-based counter-transport model of neurotransmitter transport explores the amphetamine action. Mol Pharmacol 67, 140-151.

Siegle, I., Fritz, P., Eckhardt, K., Zanger, U. M., Eichelbaum, M., 2001. Cellular localization and regional distribution of CYP2D6 mRNA and protein expression in human brain. Pharmacogenetics 11, 237-245.

Simmler, L. D., Buser, T. A., Donzelli, M., Schramm, Y., Dieu, L. H., Huwyler, J., Chaboz, S., Hoener, M. C., Liechti, M. E., 2013. Pharmacological characterization of designer cathinones in vitro. Br J Pharmacol 168, 458-470.

Sitte, H. H., Freissmuth, M., 2015. Amphetamines, new psychoactive drugs and the monoamine transporter cycle. Trends Pharmacol Sci 36, 41-50.

Sitte, H. H., Huck, S., Reither, H., Boehm, S., Singer, E. A., Pifl, C., 1998. Carrier-mediated release, transport rates, and charge transfer induced by amphetamine, tyramine, and dopamine in mammalian cells transfected with the human dopamine transporter. J Neurochem 71, 1289-1297.

Sitte, H. H., Scholze, P., Schloss, P., Pifl, C., Singer, E. A., 2000. Characterization of carriermediated efflux in human embryonic kidney 293 cells stably expressing the rat serotonin transporter: a superfusion study. J Neurochem 74, 1317-1324.

Sparago, M., Wlos, J., Yuan, J., Hatzidimitriou, G., Tolliver, J., Dal Cason, T. A., Katz, J., Ricaurte, G., 1996. Neurotoxic and pharmacologic studies on enantiomers of the Nmethylated analog of cathinone (methcathinone): a new drug of abuse. J Pharmacol Exp Ther 279, 1043-1052.

Spiller, H. A., Ryan, M. L., Weston, R. G., Jansen, J., 2011. Clinical experience with and analytical confirmation of "bath salts" and "legal highs" (synthetic cathinones) in the United States. Clin Toxicol (Phila) 49, 499-505. 
Styszko, K., Dudarska, A., Zuba, D., 2016. The Presence of Stimulant Drugs in Wastewater from Krakow (Poland): A Snapshot. Bull Environ Contam Toxicol 97, 310-315.

Torres, G. E., Gainetdinov, R. R., Caron, M. G., 2003. Plasma membrane monoamine transporters: structure, regulation and function. Nat Rev Neurosci 4, 13-25.

Tyrkko, E., Andersson, M., Kronstrand, R., 2016. The Toxicology of New Psychoactive Substances: Synthetic Cathinones and Phenylethylamines. Ther Drug Monit 38, 190-216. van Bree, J. B., de Boer, A. G., Danhof, M., Ginsel, L. A., Breimer, D. D., 1988.

Characterization of an "in vitro" blood-brain barrier: effects of molecular size and lipophilicity on cerebrovascular endothelial transport rates of drugs. J Pharmacol Exp Ther 247, 1233-1239.

Vouga, A., Gregg, R. A., Haidery, M., Ramnath, A., Al-Hassani, H. K., Tallarida, C. S., Grizzanti, D., Raffa, R. B., Smith, G. R., Reitz, A. B., Rawls, S. M., 2015. Stereochemistry and neuropharmacology of a 'bath salt' cathinone: $S$-enantiomer of mephedrone reduces cocaine-induced reward and withdrawal in invertebrates. Neuropharmacology 91, 109116.

Waterhouse, R. N., 2003. Determination of lipophilicity and its use as a predictor of blood-brain barrier penetration of molecular imaging agents. Mol Imaging Biol 5, 376389.

Zona, L. C., Grecco, G. G., Sprague, J. E., 2016. Cooling down the bath salts: Carvedilol attenuation of methylone and mephedrone mediated hyperthermia. Toxicol Lett 263, 11-15.

World Drug Report 2016: United Nations Office on Drugs and Crime, World Drug Report 2016 (United Nations publication, Sales No. E.16.XI.7) 


\section{Figure Legends}

Figure 1: Chemical structures of the stereoisomers of the phase-1 metabolites of mephedrone.

Figure 2: Effects of the stereoisomers of nor-, 4-OH- and dihydro-mephedrone on transporter-mediated uptake into HEK293 cells. Uptake of $\left[{ }^{3} \mathrm{H}\right] \mathrm{MPP}+(\mathrm{DAT}$ and NET expressing cells) and $\left[{ }^{3} \mathrm{H}\right] 5$-HT (SERT expressing cells) was inhibited with increasing concentrations of the indicated test drugs. Data are shown as the mean and SEM obtained from 5 individual experiments, performed in triplicate.

Figure 3: $S$ - and $R$-nor-mephedrone induced reverse transport via human SERT. HEK293 cells stably expressing hSERT were preloaded with tritiated 5-HT and superfused with buffer. After the collection of three 2-minute fractions, the test drugs were added at the indicated concentrations for five 2-minute fractions. (A) and (C) depict the effects of increasing concentrations of test drugs on the fractional release of $\left[{ }^{3} \mathrm{H}\right] 5-\mathrm{HT}$. (B) and (D) show the concentration response curves generated in (A) and (C). The Averaged efflux rate was defined as the mean of the last three rates (i.e. $t=8$ to 14 $\mathrm{min}$ ) minus the mean of the first three rates (i.e. basal release; i.e. $\mathrm{t}=0$ to $4 \mathrm{~min}$ ). All data are mean and SEM. $\Phi, \#, *, \wedge$ denote significant differences versus the time-matched control $(0 \mu \mathrm{M})$ for $100,30,10$ and $3 \mu \mathrm{M}$ of test drug, respectively $(P<0.05$, Bonferroni's). Numbers in parenthesis indicate independent observations performed in duplicate as described in materials and methods. $S$-nor-mephedrone: $0 \mu \mathrm{M}(9), 1 \mu \mathrm{M}$ (10), $3 \mu \mathrm{M}$ (10), $10 \mu \mathrm{M}$ (8), $30 \mu \mathrm{M}$ (10), $100 \mu \mathrm{M}$ (10). $R$-nor-mephedrone: $0 \mu \mathrm{M}$ (5), $1 \mu \mathrm{M}$ (6), $3 \mu \mathrm{M}$ (7), $10 \mu \mathrm{M}$ (11), $30 \mu \mathrm{M}(8), 100 \mu \mathrm{M}$ (7).

Figure 4: $S$ - and $\boldsymbol{R}$-4-OH-mephedrone induced reverse transport via human SERT. The experiment was performed as described in materials and methods and Figure 2. (A) and (C) depict the effects of increasing concentrations of test drugs on the fractional release of [ $\left.{ }^{3} \mathrm{H}\right] 5-\mathrm{HT}$. (B) and (D) show the concentration response curves generated in (A) and (C). The Averaged efflux rate was defined as the mean of the last three rates (i.e. $\mathrm{t}=8$ to $14 \mathrm{~min}$ ) minus the mean of the first three rates (i.e. basal release; i.e. $\mathrm{t}=0$ to 4 min). All data are mean and SEM. $\Phi, \#, *$ denote significant differences versus the timematched control $(0 \mu \mathrm{M})$ for 100,30 and $10 \mu \mathrm{M}$ of test drug, respectively $(P<0.05$, 
Bonferroni's). Numbers in parenthesis indicate independent observations performed in duplicates as described in materials and methods. $S$-4-OH-mephedrone: $0 \mu \mathrm{M}(10), 1 \mu \mathrm{M}$ (11), $3 \mu \mathrm{M}$ (12), $10 \mu \mathrm{M}$ (12), $30 \mu \mathrm{M}$ (12), $100 \mu \mathrm{M}$ (12). $R$-4-OH-mephedrone: $0 \mu \mathrm{M}(8), 1$ $\mu \mathrm{M}$ (10), $3 \mu \mathrm{M}$ (10), $10 \mu \mathrm{M}$ (9), $30 \mu \mathrm{M}$ (10), $100 \mu \mathrm{M}$ (10).

Figure 5: Chromatographic separation of derivatized $S$ - and $R$-nor-mephedrone in human urine sample as pilot study. The urine sample was derivatized as described in the methods section and then analysed on a tandem-LC-MS/MS tandem system with an analytical HPLC column (Kinetex $1.7 \mu \mathrm{m} \mathrm{C18} 100 \mathrm{~A} 150 \times 2.1 \mathrm{~mm}$ at $40^{\circ} \mathrm{C}$ using gradient conditions (35\% acetonitrile to 100\% over 26 minutes, followed by isocratic elution for 4 minutes)). The experiment was repeated twice, derivatizing $250 \mu \mathrm{L}$ of the urine sample, yielding comparable results. 